\title{
COMMENT
}

\section{Paediatric virology and medical terminology}

\author{
IOANNIS N. MAMMAS ${ }^{1-4}$, SIMON B. DRYSDALE ${ }^{5,6}$, MARIA THEODORIDOU ${ }^{1,4}$, \\ ANNE GREENOUGH ${ }^{7,8}$ and DEMETRIOS A. SPANDIDOS ${ }^{1,3}$ \\ ${ }^{1}$ Institute of Paediatric Virology; ${ }^{2}$ Paediatric Clinic, Aliveri, 34500 Island of Euboea; \\ ${ }^{3}$ Laboratory of Clinical Virology, Medical School, University of Crete, 71003 Heraklion; \\ ${ }^{4}$ First Department of Paediatrics, University of Athens School of Medicine, 11527 Athens, Greece; \\ ${ }^{5}$ St George's, University of London, London SW17 0RE; ${ }^{6}$ Department of Paediatric Infectious Diseases, \\ St. George's University Hospitals NHS Foundation Trust, London SW17 0QT; ${ }^{7}$ Department of Women and \\ Children's Health, School of Life Course Sciences and Mediicne, King's College London, London SE5 9RS; \\ ${ }^{8}$ Asthma UK Centre in Allergic Mechanisms of Asthma, King's College London, London SE1 9RT, UK
}

Received July 31, 2020; Accepted October 24, 2020

DOI: $10.3892 / \mathrm{etm} .2020 .9431$

'we should perceive directly and without any demonstration the meaning of the words'

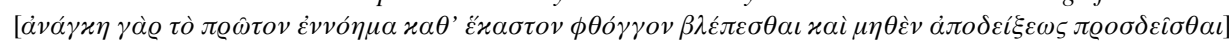

Epicurus

Medical terminology is a significant tool in medical education, as the meaning of words has great value in medicine. Scientific terms should be precise and consistent, and should not cause confusion. For this reason, the selection of the most appropriate term to describe a new virus, syndrome, procedure or medical specialty should be performed carefully. According to Epicurus, the ancient Greek philosopher, who was born on the island of Samos during the 3rd century B.C. and founded one of the most influential schools of philosophy in the ancient world, the meaning of each word is a fundamentally necessary concept and should be clear without causing misunderstanding or requiring explanation (1).

'Paediatric virology' is a medical term from the middle of the 20th century, which derived from three ancient Greek

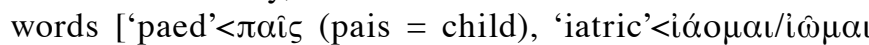
(iaome/iome $=$ to be treated) and 'logy'< $<$ ó $\gamma \circ \varsigma(\operatorname{logos}=$ study)],

Correspondence to: Professor Demetrios A. Spandidos, Laboratory of Clinical Virology, Medical School, University of Crete, 71003 Heraklion, Greece

E-mail: spandidos@spandidos.gr

Dr Ioannis N. Mammas, Paediatric Clinic, Aliveri, 34500 Island of Euboea, Greece

E-mail: mammasjo@googlemail.com

Key words: paediatric virology, children's virology, paedovirology, medical terminology and one Latin word ['viro'<virus]; the term 'paediatric virology' refers to the scientific field of virology, within the specialty of paediatrics. It encompasses the study of the basic science of viruses, the epidemiology of viral infections in children, and the diagnosis and management of children with viral infections or at risk of developing viral infections (2-4). The presence of four words in this term is accurate, meaningful and helpful to describe the characteristics of this new subspecialty, which:

a) deals with children of all ages $<18$ years old, including neonates; b) focuses on treatment (if we want to be etymologically precise) or management (if we use the general medical meaning for the term 'iatric') of viral infections, a required aim which should be further developed in the future in this field (4); c) its subject are viruses and viral infections; and d) as a scientific field is based on studying and knowledge (Fig. 1).

This term is in accordance with the respective terms used in the English language for other medical subspecialties, such as 'paediatric gastroenterology' or 'paediatric radiology' or 'paediatric neurology'; all these terms are used to describe subspecialties of medicine that are involved in paediatric clinical practice. Subsequently, 'paediatric virologist' is the paediatric health professional, who is trained in paediatric viral infections and is an expert in paediatric virology.

An alternative term that could be used for 'paediatric virology' is 'children's virology', which refers to the study of viral infections occurring in children. The term 'children's virology' derives from three ('children', 'viro', 'logy') instead of four words and its meaning is accurate and highly descriptive despite the absence of the word 'iatric', which is present in 'paediatric virology'. This absence does not change the descriptive accuracy of the required meaning of this term 


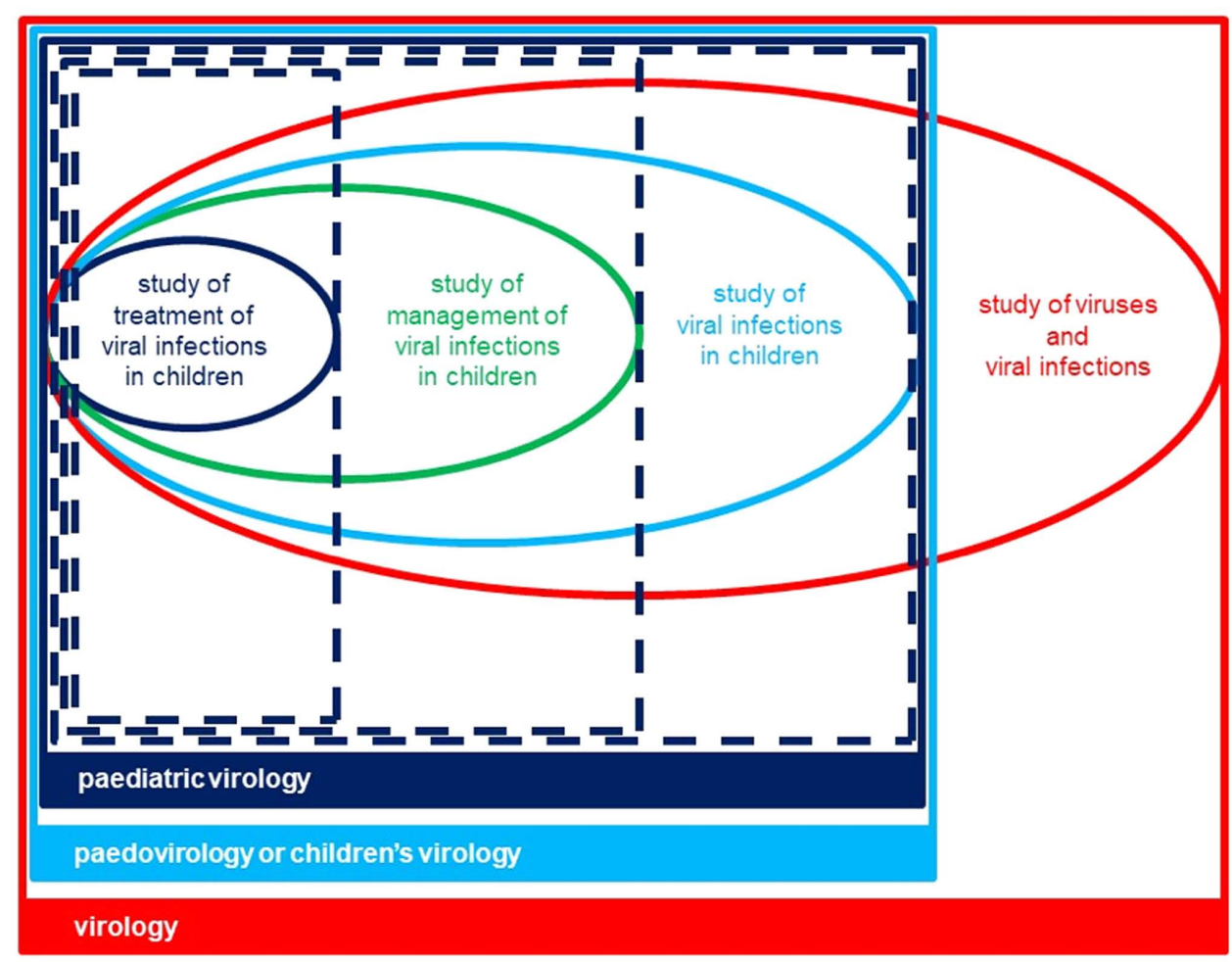

Figure 1. Etymology-based definitions of paediatric virology, children's virology, paedovirology and virology.

since the word 'logos', used extensively to describe the study of a branch of science, includes the meaning of 'iatric'. Similarly, the term 'children's hospital' is alternatively used to describe a 'paediatric hospital', where the meaning of the words 'iatric' and 'hospital' is also repeated.

An alternative new medical term for 'children's virology' could be 'paedovirology', where the ancient Greek word 'paedo' replaces the word 'children'. This term expresses accurately the same meaning as 'children's virology' and it does not contain words with repeated meaning. The main advantages of 'paedovirology' are that a) it is a one-word term; b) it fulfills the principle of the linguistic economy; and c) it is easily pronounced. Subsequently, the scientist who studies viral infections occurring in children could be called 'paedovirologist'.

In the Greek language, where the ancient Greek word 'ıós' (ios) is used instead of the Latin word 'virus' (5), the term ' $\pi \alpha \iota \delta o \ddot{o} \lambda_{0} \gamma i \alpha^{\prime}$ ' (paedoiologia) could alternatively be used instead of the translated current term ' $\pi \alpha \iota \delta \iota \alpha \tau \iota \iota x \eta ~ \iota о \lambda о \gamma i ́ \alpha$ ' (paediatriki iologia). Moreover, the Greek term ' $\pi \alpha \iota \delta \iota \tau \varrho \iota x o ́ s$

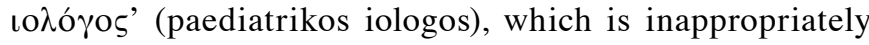
translated by the English term 'paediatric virologist', should be replaced by the term ' $\pi \alpha \iota \delta o i ̈ o \lambda o ́ \gamma o \varsigma$ ' (paedoiologos). Similarly, the English term 'paediatric gastroenterology' is translated to the Greek language to ' $\pi \alpha \iota \delta \iota \alpha \tau \varrho \iota x$ ' $\gamma \alpha \sigma \tau \varrho \varepsilon v \tau \varepsilon \varrho o \lambda o \gamma i ́ \alpha$ ' (paediatriki gastrenterologia) as well as ' $\pi \alpha \iota \delta о \gamma \alpha \sigma \tau \varrho \varepsilon v \tau \varepsilon \varrho o \lambda o \gamma i ́ \alpha$ ' (paedogastrenterologia), but the term 'paediatric gastrenterologist' is translated into ' $\pi \alpha \iota \delta о \gamma \alpha \sigma \tau \varrho \varepsilon v \tau \varepsilon \varrho o \lambda o ́ \gamma o \varsigma$ ' (paedogastrenterologos) instead of ' $\pi \alpha \iota \delta \iota \alpha \tau \varrho \iota x o ́ s ~ \gamma \alpha \sigma \tau \varrho \varepsilon v \tau \varepsilon \varrho o \lambda o ́ \gamma \circ \varsigma$ ' (paediatrikos gastrenterologos).

According to Professor George Babiniotis, Professor of Linguistics and former Rector at the University of Athens, the correct Greek terms for ' $\pi \alpha \iota \delta o \ddot{o} \lambda \mathrm{o} \gamma \mathbf{\gamma} \alpha$ ' (paedoiologia)

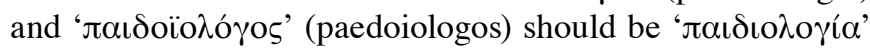
(paediologia) and ' $\pi \alpha \iota \delta ı \lambda_{\text {ó }} \sigma \mathrm{s} \varsigma$ ' (paediologos) due to the fact that the first letter in the word 'ı the letter 'o' of ' $\pi \alpha \iota \delta o$ ' (paedo) in the words ' $\pi \alpha \iota \delta o i ̈ o \lambda o \gamma i ́ \alpha$ ' (paedoiologos) and ' $\pi \alpha \iota \delta o i ̈ o \lambda o ́ \gamma o \varsigma$ ' (paedoiologos) should be deleted (Babiniotis G: personal communication). Similarly, following the same linguistic rule, in the Greek language, it is said ' $\pi \alpha \iota \delta$ í $\alpha € \circ \varsigma^{\prime}$ (paediatros), ' $\pi \varepsilon ́ v \tau \alpha \theta \lambda \mathrm{o}$ ' (pentathlon),

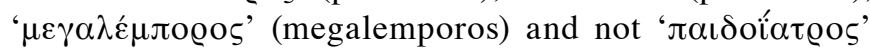

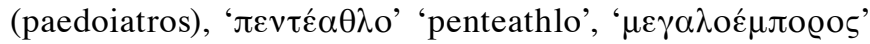
(megaloemporos). However, in this case, due to the absence of the letter 'o', ' $\pi \alpha \iota \delta ı$ ' (paedio) would mean 'child' and not 'child+virus' - in the ancient Greek language the word ' $\pi \alpha \iota \delta$ íov' (paedion) means the 'small child', while the same word during the Byzantine times replaced the ancient Greek word ' $\pi \alpha \hat{\imath} \varsigma$ ' (paes). Due to this misunderstanding

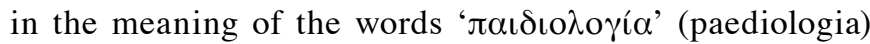

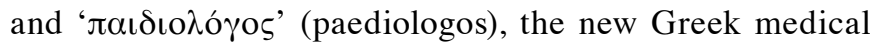

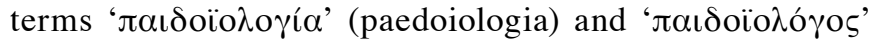
(paedoiologos) are preferable.

Nevertheless, the terms 'paediatric virology' and 'paediatric virologist' are highly informative medical terms, which emphasize the medical focus of this scientific field, which definitely should be further developed in the forthcoming years. Despite their linguistic weakness, 'paediatric virology' and 'paediatric virologists' will probably continue to be preferred and used in the English language due to their accordance with current international medical terminology. The terms 'children's virology' and 'children's virologist' are linguistically correct, accurate, and highly descriptive, easily pronounced terms, which do not contain words with repeated meaning. Additionally, the new terms 'paedovirology' and 
'paedovirologist' are one-word terms, which fulfill the fundamental principles of creating medical terminology preferably with one-word rather than multiple-words terms and use words with different and not the same or equivalent meaning. In the Greek language, the new terms ' $\pi \alpha$ เooïo $\lambda$ ó $\gamma \circ \varsigma^{\prime}$ (paedoiologos)

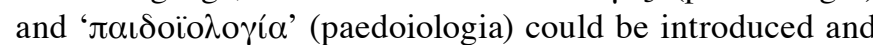

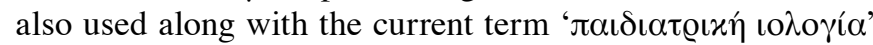
(paediatriki iologia).

\section{Acknowledgements}

This article is published in the context of the foundation of the Institute of Paediatric Virology (IPV; https:// paediatricvirology.org) based on the island of Euboea (Greece), under the auspices of the World Academy of Sciences (WAS) and the support of the Department of Clinical Virology of the University of Crete School of Medicine and the First Department of Paediatrics of the University of Athens School of Medicine. We would like to thank all the members of the IPV for their valuable comments and corrections.

\section{Funding}

No funding was received.

\section{Availability of data and materials}

Not applicable.

\section{Authors' contributions}

All authors (INM, SBD, MT, AG and DAS) contributed to the conception and design of this manuscript, wrote the original draft, edited and critically revised the manuscript, read and approved the final manuscript.

\section{Ethics approval and consent to participate}

Not applicable.

\section{Patient consent for publication}

Not applicable.

\section{Competing interests}

INM, DAS and MT are Co-founders of the Institute of Paediatric Virology (IPV). SBD is Member of the Advisory Academic Board (AAB) of the IPV. AG is Chair of the Advisory Academic Board (AAB) of the IPV. DAS is the Editor-in-Chief for the journal, but had no personal involvement in the reviewing process, or any influence in terms of adjudicating on the final decision, for this article.

\section{References}

1. Epicurus, Apanta. Kaktos Editions, Athens, 1994 (In Greek).

2. Mammas IN, Greenough A, Theodoridou M and Spandidos DA: Paediatric Virology: A new paediatric subspecialty? A proposal at the Workshop on Paediatric Virology, Athens, October 10, 2015. Exp Ther Med 11: 3-5, 2016.

3. Mammas IN, Greenough A, Theodoridou M and Spandidos DA: Educational pathways in Paediatric Virology: Pros and cons. Exp Ther Med 18: 3260-3262, 2019.

4. Mammas IN, Greenough A, Theodoridou M and Spandidos DA: Does Europe need paediatric virologists? Exp Ther Med 16: 2783-2784.

5. Babiniotis G: Dictionary of modern Greek language. Kentro Lexikologias Editions, Athens, 2019 (In Greek). International (CC BY-NC-ND 4.0) License. 